\title{
Sire breed effect on carcass and temperament traits
}

\section{Efeito da raça do touro sobre as características de carcaça e temperamento}

\author{
Leandro Lunardini Cardoso ${ }^{1 *}$; Joal José Brazzale Leal'; Marcelo Henrique \\ Giordano Nunes ${ }^{3}$; Bruno Borges Machado Teixeira ${ }^{3}$; Bruna Pena Sollero²; \\ Isabella Dias Barbosa Silveira'; Fernando Flores Cardoso ${ }^{2}$
}

\begin{abstract}
This paper aimed to identify and evaluate the effects of sire breed on temperament and productive traits of different cross-breeds between Nellore (NE), Tabapua (TB), and Brahman (BR) bulls mated with Angus cows (AN), as well as the relationship between temperament and productive traits. The productive traits measured in this study include slaughter weight and post weaning weight gain. Temperament was assessed by flight-speed (FS). Carcass data collected in this study include hot carcass weight, hot carcass percentage, cold dressing percentage, carcass length, initial $\mathrm{pH}$, ultimate $\mathrm{pH}$, subcutaneous fat thickness and carcass longissimus muscle area. The sire breed effect was greater for slaughter weight. Hot carcass weight was not affected by the sire breed. The longissimus muscle area was larger for AN $x$ TB and AN x NE crossbreeds than for AN x BR crossbreeds. Subcutaneous fat thickness and cold dressing percentage were not affected by sire breed. The offspring of NE, TB, and BR sires mated with AN cows had similar carcass measurements, except for the longissimus muscle area, which was smaller for offspring sired by the Brahman breed. The temperament trait was not influenced by sire breed.
\end{abstract}

Key words: Beef cattle. Bos indicus. Cattle temperament. Flight. pH.

\section{Resumo}

Este artigo teve como objetivo identificar o efeito da raça do touro sobre o temperamento, características produtivas e a relação entre esses efeitos avaliando-se diferentes cruzamentos entre Nelore (NE), Tabapuã (TB) e Brahman (BR) acasalados com vacas Angus (AN). As características produtivas foram peso vivo ao abate e ganho pós desmama. As características de temperamento foram mensuradas por velocidade de fuga (VF). Os dados de carcaça avaliados foram o peso de carcaça quente, rendimento de carcaça quente, rendimento de carcaça fria, comprimento de carcaça, $\mathrm{pH}$ inicial, $\mathrm{pH}$ final, espessura de gordura subcutânea e área do músculo Longissimus. O efeito da raça do touro foi maior para o peso vivo ao abate. O peso de carcaça quente não foi afetado pela raça do touro. A área do músculo Longissimus foi maior para o cruzamento AN x TB e AN x NE do que AN x BR. A espessura de gordura subcutânea

1 Discente, Curso de Pós-Doutorado do Programa de Pós-Graduação em Bioinformática e Estatística Genômica, Empresa Brasileira de Pesquisa Agropecuária, EMBRAPA Pecuária Sul, Bagé, RS, Brasil. E-mail: lunardini.cardoso@ufrgs.br

2 Pesquisadores, EMBRAPA Pecuária Sul, Bagé, RS, Brasil. E-mail: joal.leal@embrapa.br; bruna.sollero@embrapa.br; fernando. cardoso@embrapa.br

3 Discentes, Curso de Mestrado, Programa de Pós-Graduação em Zootecnia, Universidade Federal de Pelotas, Faculdade de Agronomia Eliseu Maciel, Departamento de Zootecnia, PPGZ/UFPEL. E-mail: marcelohgn@gmail.com; bteixeira@veterinario. med.br

${ }^{4}$ Prof $^{\mathrm{a}}$, Universidade Federal de Pelotas, Faculdade de Agronomia Eliseu Maciel, Departamento de Zootecnia, PPGZ/UFPEL, Pelotas, RS, Brasil. E-mail: barbosa-isabella@hotmail.com

* Author for correspondence 
e rendimento de carcaça fria não foram afetadas pelo efeito da raça do touro. Os animais descendentes de touros NE, TB e BR acasalados com vacas AN tiveram medidas de carcaça similares, exceto para a area do músculo Longissimus, o qual foram menores para os animais descendentes de touros Brahman. $\mathrm{O}$ temperamento não foi influenciado pelo efeito da raça do touro.

Palavras-chave: Bovinos de corte. Bos indicus. Temperamento. Velocidade de fuga. pH.

\section{Introduction}

One of the goals of the beef industry is to consistently produce a tender and cost effective product, as well to reduce losses from injuries on carcasses. It is known that the temperament of cattle affects the final meat quality (COOMBES et al., 2014). Temperament is associated with stress, and the stress level of cattle also affects the quality of meat. The magnitude of the stress response is affected by individual differences, and this response may negatively influence the efficiency of the immunologic response, reproduction, and development of cattle (MOBERG; MENCH, 2000). Reactive animals may be more susceptible to stress generated by routine handling and consequently, this trait may negatively affect productivity (CAFE et al., 2011). More reactive animals such as zebu cattle also tend to present increased amounts of bruise trim due to injuries acquired during transportation (MENDONÇA et al., 2017).

Temperament may vary according to an animal's genotype. Zebu cattle tend to have a more excitable temperament than Angus cattle (CAFE et al., 2011). When an animal is subjected to a stressful stimulus, an increased heart rate and blood glucose levels can be observed due to the rapid breakdown of glycogen in the liver. In addition, reactive animals spend more muscular glycogen before slaughter, reducing the glycogen concentration in meat below around 8 $\mathrm{mg} \mathrm{g}^{-1}$, which results in the elevation of the ultimate $\mathrm{pH}$ and reduction of postmortem muscle protein denaturation (WARRISS, 2010).

Evaluation of carcass traits from different breeds or cross-breeds is important for determining the potential value of alternative germplasm resources for profitable beef production (WHEELER et al.,
2010). In beef cattle, carcass weight is the main measure used by the slaughterhouses for payment, ribeye area indicates the amount of meat in the carcass, and a minimum of back fat thickness is necessary to protect the carcass during cooling (WARRIS, 2010; FERNANDES JÚNIOR et al., 2016). Moreover, temperament affects growth and carcass traits of Bos indicus and Bos taurus cattle, and animals with poorer temperament (i.e. more reactive animals), as assessed by flight-speed, had consistently slower growth rates, smaller carcasses, less fat cover, and worse meat quality traits (CAFE et al., 2011).

The present study was conducted to identify the effect of sire breed on temperament, productive traits, and the relationship between these traits using different cross-breeds between Nellore (NE), Tabapua (TB), and Brahman (BR) sires mated with Angus cows (AN).

\section{Material and Methods}

This study was conducted in Bagé, Rio Grande do Sul state, Brazil (latitude South 31 ${ }^{\circ} 20^{\prime}$ 59.71"; longitude West 54 00'58.33”), between April 2003 and May 2007.

Animals and management: Twenty-seven castrated steers were continuously grass-fed with natural pasture under extensive management conditions until their slaughter (at 39.0 \pm 0.4 months of age). The steers were generated through a planned crossbreeding experiment (using artificial insemination) that included matings between Angus cows and Nellore $(n=3)$, Brahman $(n=1)$, and Tabapua $(\mathrm{n}=2)$ bulls, from April $15^{\text {th }}$ to April $30^{\text {th }}$ of 2003. The resulting crossbreed $F_{1}$ steers were 
born between January $26^{\text {th }}$ and March $9^{\text {th }}, 2004$ and included the following breed compositions: $1 / 2$ Nellore (NE) $1 / 2$ Angus (AN) $(n=11), 1 / 2$ AN $1 / 2$ Brahman (BR) $(n=8)$, and $1 / 2$ AN $1 / 2$ Tabapua (TB) $(n=8)$. From birth to slaughter, steers were kept exclusively on native pasture and managed under extensive conditions. The fields steers were grazed on consisted predominantly of grassland, but also included the following: 1) an open formation, known as "clean grassland", which consisted of a low, continuous layer of grasses and herbs; 2) a "dirty field" that differed from the "clean grassland" by the presence of shrubs and subshrubs; 3 ) areas known as "broom fields", consisting of Baccharis spp. and Dodonaea viscosa; and 4) mixed areas of lowlands and island spots of bushes and small woods. All experimental procedures were in accordance with the Conselho Nacional de Controle e Experimentação Animal - CONCEA (http://www. mct.gov.br/index.php/content/view/310553.html).

Measurements: Temperament was individually assessed using flight-speed measurements $1 \mathrm{~d}$. before slaughter. Flight-speed (FS) is the amount of time, in seconds, that it takes a steer to cover a fixed distance $(2 \mathrm{~m})$ after it leaves the restraining device. Flight-speed ( $\mathrm{FS}=2 / \mathrm{FT})$, where $\mathrm{FT}$ is the flight time in seconds, corresponds to the speed of the steer while leaving the chute. The slaughter weights (SLW, kg) were measured before slaughter. The steers were transported to a commercial slaughterhouse in Bagé, Rio Grande do Sul, 5 km away from the production unit, and remained in lairage pens for $24 \mathrm{~h}$ before slaughter. Hot carcass weight was obtained at slaughter $(\mathrm{HCW}, \mathrm{kg})$ and the cold carcass weight (CCW, $\mathrm{kg}$ ) was obtained $24 \mathrm{~h}$ after slaughter. Hot carcass percentage (HCP, kg/100 $\mathrm{kg}$ body weight) was calculated using the following equation: $\mathrm{HCP}=(\mathrm{HCW} / \mathrm{SLW}) \times 100$, and the cold dressing percentage (CDP, $\mathrm{kg} / 100 \mathrm{~kg}$ body weight) was calculated using the following equation: CDP $=(\mathrm{CCW} / \mathrm{SLW}) \times 100$. The carcass length $(\mathrm{CL}$, $\mathrm{mm}$ ) was measured using a measuring tape from the cranial border of the middle portion of the first rib to the cranial border of the pubic bone. Arm perimeter (AP, mm) was similarly measured from the olecranon tuberosity to the distal end of the humerus. The leg length (LL, cm), was measured from the pubic bone to the tibiotarsal joint. The carcass $\mathrm{pH}$ was measured 45 min after slaughter $\left(\mathrm{pH}_{\mathrm{i}}\right)$ and 24 h post mortem $\left(\mathrm{pH}_{\mathrm{u}}\right)$ in the longissimus muscle between the $12^{\text {th }}$ and $13^{\text {th }}$ rib, using a digital $\mathrm{pH}$ meter (Testo ${ }^{\circledR}$ model 205). Brazilian Agricultural Research Corporation (EMBRAPA) meat scientists measured the carcass subcutaneous fat thickness (CFAT, mm), and the carcass longissimus muscle area (CLMA). The carcass fat thickness was measured with a steel ruler, and CLMA was measured with a USDA grid between the $12^{\text {th }}$ and $13^{\text {th }}$ rib. All carcass traits were collected according to Boggs and Merkel (1990).

\section{Statistical analysis}

Descriptive statistics were employed for each experiment using the MEANS procedure of SAS (Statistical Analysis System, version 8.1). Univariate and multivariate analyses of variance were performed for the evaluated traits using the $\mathrm{SAS}^{\circledR}$ GLM procedure. The general model used for all traits was follows:

$$
y_{i j}=\mu+G_{i}+\Gamma_{j}+\varepsilon_{i j}
$$

where: $y_{i j}$ is the trait measured in the individual $i, \mu$ is the overall mean for the trait, $G_{i}$ is the breed of the sire (fixed effect), $\Gamma_{j}$ is the sire (random effect), and $\varepsilon_{(i j)}$ is the residual term associated with the observation.

The partial correlation coefficients between temperament measures, animal performance, and carcass traits were determined using SAS ${ }^{\circledR}$ PROC GLM from the residual covariance matrix obtained from multivariate analysis of variance. Least squares means were computed for all traits and compared by Tukey test $\left(\mathrm{SAS}^{\circledR}\right)$, in which P-values $<0.05$ were considered significant. 


\section{Results and Discussion}

The results indicate that SLW was statistically different between steers with a TB sire and steers with NE and BR sires $(P<0.05)$, and steers with TB sires were lighter than steers with NE and BR sires (Table 1). On the contrary, this pattern was not seen for HCW and CCW (Table 1), which are highly correlated to SLW, once muscle and bone developments are linearly dependent (STEWART, 1972). Similarly, Berg and Butterfield (1976) reported that the muscle mass increases proportionally to the weight of bone. Therefore, the lack of a consistent sire breed effect on SLW, HCW and $\mathrm{CCW}$ can be explained by the non-carcass components that were not studied, including the relationship between the bone and muscle mass, especially considering steers such as those in this study, which have low proportion of fat in the carcass (Table 2).
Average daily gain (ADG) was not statistically different between steers with TB, NE, and BR sires (Table 1). Huffman et al. (1990) found no significant difference between 25,50 , and $75 \%$ Brahman $\times$ Angus crossbred steers for ADG. Similarly, Schutt et al. (2009) did not find differences in ADG for Brahman $\mathrm{x}$ British crossbreeds, which is consistent with our average daily gain results, although steers in our study had lower ADG in comparison to the abovementioned studies. In general, purebred animals have lower ADG compared to crossbreeds (MAGGIONI et al., 2010). However, the degree of heterosis was the same between steers in this study, and no purebred steers were tested to assess heterosis effects. Similarly to CFAT (Table 2), the extensive grazing nutritional plan may not have been sufficient to result in high levels of ADG and detect significant differences between sire breeds.

Table 1. Sire breed effect on slaughter live weight (SLW), average daily gain (ADG), hot carcass weight (HCW), cold carcass weight $(\mathrm{CCW})$, flight-speed $(\mathrm{FS})$, initial $\left(\mathrm{pH}_{\mathrm{i}}\right)$ and final $\left(\mathrm{pH}_{\mathrm{u}}\right) \mathrm{pH}$. Least square means \pm standard error are shown.

\begin{tabular}{lccc}
\hline \multirow{2}{*}{ Trait } & \multicolumn{3}{c}{ Sire breed } \\
\cline { 2 - 4 } & Brahman (BR) & Nellore (NE) & Tabapua (TB) \\
\hline SLW (kg) & $591.00^{\mathrm{a}} \pm 12.85$ & $608.18^{\mathrm{a}} \pm 10.96$ & $559.25^{\mathrm{b}} \pm 12.85$ \\
$\mathrm{ADG}($ weaning to slaughter, g) & $447.68^{\mathrm{a}} \pm 0.01$ & $477.34^{\mathrm{a}} \pm 0.01$ & $432.99^{\mathrm{a}} \pm 0.01$ \\
$\mathrm{HCW}(\mathrm{kg})$ & $302.45^{\mathrm{a}} \pm 6.49$ & $310.94^{\mathrm{a}} \pm 5.53$ & $292.17^{\mathrm{a}} \pm 6.49$ \\
$\mathrm{CCW}(\mathrm{kg})$ & $300.62^{\mathrm{a}} \pm 6.64$ & $310.32^{\mathrm{a}} \pm 5.67$ & $288.90^{\mathrm{a}} \pm 6.64$ \\
$\mathrm{FS} \mathrm{(m/s)}$ & $1.86^{\mathrm{a}} \pm 0.32$ & $1.94^{\mathrm{a}} \pm 0.27$ & $2.39^{\mathrm{a}} \pm 0.32$ \\
$\mathrm{pH}_{\mathrm{i}}$ & $6.49^{\mathrm{a}} \pm 0.16$ & $6.45^{\mathrm{a}} \pm 0.13$ & $6.56^{\mathrm{a}} \pm 0.16$ \\
$\mathrm{pH}_{\mathrm{u}}$ & $5.53^{\mathrm{a}} \pm 0.02$ & $5.60^{\mathrm{a}} \pm 0.02$ & $5.56^{\mathrm{a}} \pm 0.02$ \\
\hline
\end{tabular}

Least square means within a row different letter differ significantly $(\mathrm{P}<0.05)$. $\mathrm{pH}_{\mathrm{i}}=$ initial $\mathrm{pH} 45$ min after slaughter, $\mathrm{pH}_{\mathrm{u}}=$ ultimate $\mathrm{pH} 24 \mathrm{~h}$ after slaughter.

There were no significant differences in flightspeed (FS) between NE, TB, and BR sire breeds (Table 1). The average FS obtained in the present study was similar to those found in the literature for Brahman cattle and their crosses, whose flightspeed ranged from 0.59 to $2.83 \mathrm{~m} / \mathrm{s}$ (PETHERICK et al., 2009). Hoppe et al. (2010) found a significant effect of breed on FT $(\mathrm{P}<0.001)$ among Bos taurus breeds (German Angus, Hereford, German Simmental, Charolais, and Limousin). According to Grandin (1997), determining the amount of stress in farm animals generates highly variable results, and these results are difficult to interpret. 
Table 2. Sire breed effect on carcass longissimus muscle area (CLMA), carcass fat depth (CFAT), leg length (LL), carcass length (CL), arm perimeter (AP) and carcass dressing percentage (CDP). Least square means \pm standard error are shown.

\begin{tabular}{lccc}
\hline \multirow{2}{*}{ Trait } & \multicolumn{3}{c}{ Bull breed } \\
\cline { 2 - 4 } & Brahman $(\mathrm{BR})$ & Nellore $(\mathrm{NE})$ & Tabapua $(\mathrm{TB})$ \\
\hline CLMA $\left(\mathrm{cm}^{2}\right)$ & $68.47^{\mathrm{b}} \pm 2.31$ & $74.60^{\mathrm{ab}} \pm 1.97$ & $77.26^{\mathrm{a}} \pm 2.31$ \\
CFAT $(\mathrm{mm})$ & $4.12^{\mathrm{a}} \pm 0.57$ & $3.36^{\mathrm{a}} \pm 0.48$ & $3.62^{\mathrm{a}} \pm 0.57$ \\
LL $(\mathrm{cm})$ & $89.43^{\mathrm{a}} \pm 1.23$ & $91.40^{\mathrm{a}} \pm 1.05$ & $88.18^{\mathrm{a}} \pm 1.23$ \\
CL $(\mathrm{cm})$ & $145.18^{\mathrm{a}} \pm 1.74$ & $144.31^{\mathrm{ab}} \pm 1.48$ & $138.43^{\mathrm{b}} \pm 1.74$ \\
AP $(\mathrm{cm})$ & $45.93^{\mathrm{a}} \pm 0.69$ & $45.22^{\mathrm{a}} \pm 0.59$ & $45.00^{\mathrm{a}} \pm 0.69$ \\
CDP $(\mathrm{kg} / 100$ kg body weight $)$ & $50.87^{\mathrm{a}} \pm 0.35$ & $51.02^{\mathrm{a}} \pm 0.29$ & $51.68^{\mathrm{a}} \pm 0.35$ \\
\hline
\end{tabular}

Least square means within a row different letter differ significantly $(\mathrm{P}<0.05)$.

There were no significant differences $(\mathrm{P}>$ 0.05 ) in initial $\mathrm{pH}$ between sire breeds (Table 1). Furthermore, the sire breed did not significantly affect the ultimate $\mathrm{pH}_{\mathrm{u}}(\mathrm{P}>0.05)$. Therefore, sire breed did not affect the final meat quality and, it is possible that sire breed does not affect the endogenous calpains proteolytic system, which is $\mathrm{pH}$-dependent. The $\mathrm{pH}_{\mathrm{u}}$ is inversely proportional to the concentration of lactate and the initial glycogen concentration (WARRISS, 2010), thus a short lairage time is crucial for an appropriate reduction in $\mathrm{pH}$ (DEL CAMPO et al., 2010), since glycogen resources can be restored during lairage time (WARRISS et al., 1984). Normally, the steers need enough time to get used to the new environment, rest, and restore glycogen (DEL CAMPO et al., 2010). In this experiment, the short travelling distance to the slaughter plant and the $24 \mathrm{~h}$ lairage time were sufficient to restore muscle glycogen levels and avoid high $\mathrm{pH}$ values, which could reduce beef quality.

The longissimus muscle area is an important predictor of retail product (SILVA et al., 2012). For this reason, this measure is used for estimating yield grade, and is a general indicator of muscling in carcasses. Differences between sire breeds $(\mathrm{P}<$ 0.05) were observed for the CLMA trait, and steers with TB and NE sires had greater CLMA values than steers with BR sires (Table 2). These results suggest that using TB and NE breed sires could increase carcass yield grade, ribeye area, and cutability of steers resulting from crossbreeding with Angus cows. Maggioni et al. (2010) did not find genetic group influences on CLMA in crossbreed steers resulting from Nellore sires, including those that were $1 / 2$ Nellore x $1 / 2$ European, and $1 / 4$ Nellore $x$ $3 / 4$ European. In contrast, Marshall et al. (1987) reported significant effects of sire breed in Angus $\mathrm{x}$ Brown Swiss crosses on reciprocal $\mathrm{F}_{1}$ crossbred steers.

The carcass fatness results in the present study were similar among steers from BR, NE, and TB sires (Table 2). In contrast, a sire breed effect on the same trait was reported by Casas et al. (2010), who studied steers reared on high energy diets. However, in this study the steers were finished on natural pasture matching the minimal local market requirement of median fat ( $3-6 \mathrm{~mm})$. Also, under the present grazing conditions, sire breed effects were not large enough to induce significant differences for deposits of subcutaneous fat.

The carcass lengths of steers with NE and BR sires were greater than those of steers with $\mathrm{TB}$ sires $(\mathrm{P}<0.05)$. Although there were significant differences between breeds, the correlation between carcass length and percent boneless retail cuts was 
weak and not statistically significant. Carcass length was not correlated with CDP and CLMA (Table 3), which can explain the significant differences in the results between CLMA and CL across the breeds (Table 2).

While slaughter live weight (SLW) was highly correlated with $\mathrm{HCW}$ and $\mathrm{CCW}$, and moderately correlated with CL and LL (Table 3), it was not significantly correlated with CDP, CLMA, and CFAT. These results were similar to those found by Emenheiser et al. (2014), who reported a correlation coefficient of 0.96 between SLW and HCW. HCW and CCW are highly correlated, and have a high linear association, and have the same relationship with SLW. The correlations between SLW and other weight traits are typically higher than those explained in percentage values (SILVA et al., 2012). Although SLW is an easily obtained trait, and it was positively correlated to the weight of the carcass, it is not a good indicator of the final meat product yield. Thus, an increasing body weight, despite increasing the total weight of carcass cuts, does not represent an improvement in CDP. SLW must be combined with one or more carcass traits to determine the degree of yield (BOGGS; MERKEL, 1990).

The relationship between CL and CCW was moderate (Table 3). Cold carcass weight is an important indicator of saleable meat weight (SILVA et al., 2012). However, carcass length is not a predictor of weight and percentage of boneless retail cuts (BERRY et al., 1973). According to Hedrick (1983), linear measurements are more strongly correlated with weight than with percentage of carcass components, and carcass weight appears to be a better indicator than a single linear measurement for predicting carcass component parts.

The carcass dressing percentage was correlated only with CLMA (Table 3). According to Berg and Butterfield (1976), correlation studies should be considered with caution, since the association degree could be more influenced by the range of the data than the actual trait that is being predicted.

Table 3. Partial correlation coefficients between slaughter live weight (SLW), hot carcass weight (HCW), leg length (LL), carcass length (CL), arm perimeter (AP), cold carcass weight (CCW), carcass dressing percentage (CDP), carcass longissimus muscle area (CLMA), and carcass fat depth (CFAT).

\begin{tabular}{llllllllc}
\hline Trait & HCW & LL & CL & AP & CCW & CDP & CLMA & CFAT \\
\hline SLW & $0.92^{* * * *}$ & $0.63^{*}$ & $0.55^{* *}$ & 0.32 & $0.95^{* * * *}$ & -0.13 & 0.14 & 0.20 \\
HCW & & $0.58^{*}$ & $0.56^{*}$ & $0.37^{*}$ & $0.97^{* * * *}$ & 0.17 & 0.31 & 0.23 \\
LL & & & 0.27 & -0.08 & $0.55^{* *}$ & -0.27 & 0.21 & 0.02 \\
CL & & & & 0.15 & $0.55^{* *}$ & -0.02 & -0.02 & 0.14 \\
AP & & & & & $0.40^{* *}$ & 0.26 & 0.15 & -0.20 \\
CCW & & & & & & 0.17 & 0.29 & 0.24 \\
CDP & & & & & & & $0.49^{* *}$ & 0.13 \\
CLMA & & & & & & & & -0.13 \\
\hline
\end{tabular}

${ }^{*} \mathrm{P}<0.1,{ }^{* *} \mathrm{P}<0.01,{ }^{* * *} \mathrm{P}<0.001,{ }^{* * * *} \mathrm{P}<0.0001$.

Post mortem muscle acidification is caused by the breakdown of glycogen to lactic acid. If glycogen is depleted by stress before slaughter, then less lactic acid can be formed, and the meat does not acidify normally, resulting in the ultimate $\mathrm{pH}$ remaining high (WARRISS, 2010). In the present study, the relationship between $\mathrm{pH}_{\mathrm{i}}$ and $\mathrm{pH}_{\mathrm{u}}$ was null (Table 4). According to Warriss et al. (1984) and Del Campo et al. (2010), a short lairage time increases the ultimate $\mathrm{pH}$. Stressor effects appear to 
be additive, and the multiple stressors in the preslaughter period result in a higher $\mathrm{pH}$ than a single or few stressors that can be classified in four categories: physiological, morphometric, behavioral and meat quality (LOSADA-ESPINOSA et al., 2018). This study was conducted to reduce the stressor effects and evaluate the steers under the same conditions. Long lairage time appeared to allow steers to recover during the waiting time, and this was reflected in a better rate of glycogen recovery.

The correlation coefficient between flight-speed and initial $\mathrm{pH}$ was negative and moderate (Table 4). Steers that are more stressed pre or during slaughter are prompt to excessive muscle contractions, resulting in increased in vivo muscle glycogen expenditure and accelerated anaerobic glycolysis (CHAMPE et al., 2005), which may increase ultimate pH of muscles (TERLOUW, 2015). Nevertheless, Del Campo et al. (2010) did not report an effect of temperament on initial $\mathrm{pH}$ under normal slaughter conditions. Moreover, in this study, despite the moderately negative correlation between $\mathrm{pH}_{\mathrm{i}}$ and temperament, neither traits were associated with $\mathrm{pH}_{\mathrm{u}}$ (Table 4), which is the key $\mathrm{pH}$ measurement for meat quality. Furthermore, no association between temperament and final $\mathrm{pH}$ was observed in the study carried out by Del Campo et al. (2010).

Table 4. Partial correlations between initial $\mathrm{pH}_{\mathrm{i}}$, ultimate $\mathrm{pH}_{\mathrm{u}}$ and flight-speed (FS).

\begin{tabular}{ccc}
\hline Trait & $\mathrm{pH}_{\mathrm{u}}$ & $\mathrm{FS}(\mathrm{m} / \mathrm{s})$ \\
\hline $\mathrm{pH}_{\mathrm{i}}$ & $-0.01^{\mathrm{ns}}$ & $-0.52^{* *}$ \\
$\mathrm{pH}_{\mathrm{u}}$ & & $0.27^{\mathrm{ns}}$ \\
\hline
\end{tabular}

$\mathrm{pH}_{\mathrm{i}}=$ initial $\mathrm{pH} 45$ min after slaughter, $\mathrm{pH}_{\mathrm{u}}=$ ultimate $\mathrm{pH} 24 \mathrm{~h}$ after slaughter, $\mathrm{FS}=$ flight-speed. ${ }^{* *} \mathrm{P}<0.01$, ns $=$ non-significant.

\section{Conclusion}

The choice of the sire breed affects important productive traits of $\mathrm{F} 1 \mathrm{zebu} \times$ Angus steers, such as slaughter live weight, with favorable performance of Nellore and Brahman compared to Tabapua sired steers.

Offspring of Nellore, Tabapua, and Brahman sires mated with Angus cows have similar carcass measurements, except for longissimus muscle area, which was smaller for offspring of Brahman sires.

Sire breed did not influence temperament (measured as flight-speed); nevertheless, reactive steers within all breed compositions had a faster $\mathrm{pH}$ decline immediately after slaughter.

\section{References}

BERG, R. T.; BUTTERFIELD, R. M. New concepts of cattle growth. Sidney: Sidney University Press, 1976. $255 \mathrm{p}$.

BERRY, B. W.; SMITH, G. C.; CARPENTER, Z. L. Beef carcass length and yields of boneless retail cuts. Journal of Animal Science, Champaign, v. 37, n. 5, p. 1132-1136, 1973.

BOGGS, D. L.; MERKEL, R. A. Live animal carcass evaluation and selection manual. $3^{\text {th }}$ ed. Dubuque: Kendall Hunt Publishing Company, 1990. 227 p.

CAFE, L. L.; ROBINSON, D. L.; FERGUSON, D. M.; MCINTYRE, B. L.; GEESINK, G. H.; GREENWOOD, P. L. Cattle temperament: persistence of assessments and associations with productivity, efficiency, carcass and meat quality traits. Journal of Animal Science, Champaign, v. 89, n. 5, p. 1452-1465, 2011.

CASAS, E.; THALLMAN, R. M.; KUEHN, L. A.; CUNDIFF, L. V. Postweaning growth and carcass traits in crossbred cattle from Hereford, Angus, Brangus, Beefmaster, Bonsmara, and Romosinuano maternal 
grandsires. Journal of Animal Science, Champaign, v. 88, n. 1, p. 102-108, 2010.

CHAMPE, P. C.; HARVEY, R. A.; FERRIER, R. D. Biochemistry illustrated. $3^{\text {th }}$ ed. Philadelphia: Lippincott Williams \& Wilkins, 2005. 534 p.

COOMBES, S. V.; GARDENER, G. E.; PETHICK, D. W.; MCGILCHRIST, P. The impact of beef cattle temperament assessed using flight speed on muscle glycogen, muscle lactate and plasma lactate at slaughter. Meat Science, Barking, v. 98, n. 4, p. 815-821, 2014.

DEL CAMPO, M.; BRITO, G.; SOARES DE LIMA, J.; HERNÁNDEZ, P.; MONTOSSI, F. Finishing diet, temperament and lairage time effects on carcass and meat quality traits in steers. Meat Science, Barking, v. 86, n. 4, p. 908-914, 2010.

EMENHEISER, J. C.; TAIT, R. G.; SHACKELFORD, S. D.; KUEHN, L. A.; WHEELER, T. L.; NOTTER, D. R.; LEWIS, R. M. Use of ultrasound scanning and body condition score to evaluate composition traits in mature beef cows. Journal of Animal Science, Champaign, v. 92, n. 9, p. 3868-3877, 2014.

FERNANDES JÚNIOR, G. A.; COSTA, R. B.; CAMARGO, G. M. F. de; CARVALHEIRO, R.; ROSA, G. J. M.; BALDI, F.; GARCIA, D. A.; GORDO, D. G. M.; ESPIGOLAN, R.; TAKADA, L.; MAGALHÃES, A. F. B.; BRESOLIN, T.; FEITOSA, F. L. B.; CHARDULO, L. A. L.; OLIVEIRA, H. N. de; ALBUQUERQUE, L. G. de. Genome scan for postmortem carcass traits in Nellore cattle. Journal of Animal Science, Champaign, v. 94, n. 10, p. 4087-4095, 2016.

GRANDIN, T. Assessment of stress during transport and handling. Journal of Animal Science, Champaign, v. 75, n. 1, p. 249-257, 1997.

HEDRICK, H. B. Methods of estimating live animal and carcass composition. Journal of Animal Science, Champaign, v. 57, n. 5, p. 1316-1327, 1983.

HOPPE, S.; BRANDT, H. R.; KÖNIG, S.; ERHARDT, G.; GAULY, M. Temperament traits of beef calves measured under field conditions and their relationships to performance. Journal of Animal Science, Champaign, v. 12 , n. 6, p. 1982-1989, 2010.

HUFFMAN, R. D.; WILLIAMS, S. E.; HARGROVE, D. D.; JOHNSON, D. D.; MARSHALL, T. T. Effects of percentage Brahman and Angus breeding, age-season of feeding and slaughter end point on feedlot performance and carcass characteristics. Journal of Animal Science, Champaign, v. 68, n. 7, p. 2243-2252, 1990.

LOSADA-ESPINOSA, N.; VILLAROEL, M.; MARÍA, G. A.; MIRANDA-DE LA LAMA, G. C. Pre-slaughter cattle welfare indicators for use in a commercial abattoirs with voluntary monitoring systems: a systematic review. Meat Science, Barking, v. 138, n. 1, p. 34-48, 2018.

MAGGIONI, D.; MARQUES, J. A.; ROTTA, P. P.; PEROTTO, D.; DUCATTI, T.; VISENTAINER, J. V.; PRADO, I. N. Animal performance and meat quality of crossbred young bull. Livestock Science, Amsterdam, v. 127, n. 2, p. 176-182, 2010.

MARSHALL, T. T.; HARGROVE, D. D.; OLSON, T. A. Heterosis and additive breed effects on feedlot and carcass traits from crossing Angus and Brown Swiss. Journal of Animal Science, Champaign, v. 64, n. 5, p. 1332-1339, 1987.

MENDONÇA, F. S.; VAZ, R. Z.; VAZ, F. N.; RESTLE, J.; GONÇALVES, G. B.; VARA, C. C. da. Breed and carcass characteristics on losses by bruises and meat $\mathrm{pH}$ in beef of steers and culling cows. Ciência Animal Brasileira, Goiânia, v. 18, n. e-45295, p. 1-10, 2017.

MOBERG, G. P. A. Biological response to stress: implications for animal welfare. In: MOBERG, G. P.; MENCH, J. A. (Ed.). The biology of animal stress: basic principles and implications for animal welfare. Wallingford: CABI, 2000. v. 1, cap. 1, p. 1-21.

PETHERICK, J. C.; DOOGAN, V. J.; HOLROYD, R. G.; OLSSON, P.; VENUS, B. K. Quality of handling and holding yard environment, and beef cattle temperament: 1. Relationships with flight speed and fear of humans. Applied Animal Behavior Science, Amsterdam, v. 120, n. 1, p. 18-27, 2009.

SCHUTT, K. M.; ARTHUR, P. F.; BURROW, H. M. Brahman and Brahman crossbred cattle grown on pasture and in feedlots in subtropical and temperate Australia. 3. Feed efficiency and feeding behaviour of feedlot-finished animals. Animal Production Science, Queensland, v. 49, n. 6, p. 452-460, 2009.

SILVA, S. L.; TAROUCO, J. U.; FERRAZ, J. B. S.; GOMES, R. C.; LEME, P. R.; NAVAJAS, E. A. Prediction of retail beef yield, trim fat and proportion of high-valued cuts in Nellore cattle using ultrasound live measurements. Revista Brasileira de Zootecnia, Viçosa, MG, v. 41, n. 9, p. 2025-2031, 2012.

STEWART, D. M. The role of tension in muscle growth. In: GOSS, R. G. (Ed.). Regulation of organ and tissue growth. New York: Ed. Academic Press, 1972. v. 1, cap. 5, p. 77-100.

TERLOUW, C. Stress reactivity, stress at slaughter and meat quality. In: PRZYBYLSKI, W.; HOPKINS, D. Meat quality: genetic and environmental factors. Philadelphia: CRC Press, 2015. v. 1, cap. 7, p. 199-218. 
WARRISS, P. D. Meat science: an introductory text. Wallingford: Ed. CABI, 2010. 234 p.

WARRISS, P. D.; KESTIN, S. C.; BROWN, S. N.; WILKINS, L. J. The time required for recovery from mixing stress in young bulls and the prevention of dark cutting beef. Meat Science, Barking, v. 10, n. 1, p. 53-68, 1984.
WHEELER, T. L.; CUNDIFF, L. V.; SHACKELFORD, S. D.; KOOHMARAIE, M. Characterization of biological types of cattle (Cycle VIII): carcass, yield, and longissimus palatability traits. Journal of Animal Science, Champaign, v. 88, n. 9, p. 3070-3083, 2010. 
